\title{
Effect of Exercise-Induced Lipolysis on Serum Vitamin D Level in Obese Children: A Clinical Controlled Trial
}

\author{
Lamiaa K. Elsayyad ${ }^{1}$, Alaa Shafie ${ }^{2}$, Mazen Almehmadi $^{2}$, Amal F. Gharib $^{2}$, Ahmad El Askary $^{2}$, Tarek Alsayad ${ }^{3}$, Alsufiany Muhsen $^{1}$, \\ Hatem Allam ${ }^{1 *}$ (D) \\ ${ }^{1}$ Department of Physical Therapy, College of Applied Medical Sciences, Taif University, Taif, Saudi Arabia; ${ }^{2}$ Department of \\ Clinical Laboratory Sciences, College of Applied Medical Sciences, Taif University, Taif, Saudi Arabia; ${ }^{3}$ Department of Pediatrics, \\ Faculty of Medicine, Al-Azhar University, Cairo, Egypt
}

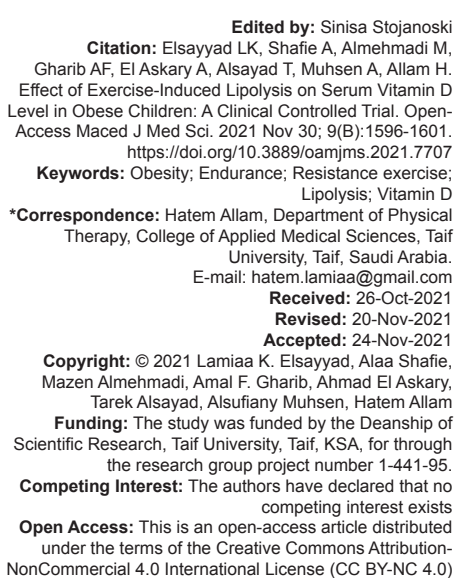

Edited by: Sinisa Stojanoski Edited by: Sinisa Stojanosk
Citation: Elsayyad LK, Shafie A, Almehmadi M, Gharib AF, EI Askary A, Alsayad T, Muhsen A, Allam H. Effect of Exercise-Induced Lipolysis on Serum Vitamin $D$ Level in Obese Children: A Clinical Controlled Trial OpenAccess Maced J Med Sci. 2021 Nov 30; 9(B):1596-1601 https://doi.org/10.3889/oamjms.2021.7707
Access Maced Keywords: Obesity; Endurance; Resistance exercise Lipolysis; Vitamin D
"Correspondence: Hatem Allam, Department of Physical Therapy, College of Applied Medical Sciences, Taif University, Taif, Saudi Arabia
E-mail: hatem.lamiaa@gmail.com Revised: : 20-Nov-2021 Revised: 20-Nov-202 Copyright: @ 2021 Lamiaa K. Elsayyad, Alaa Shafie, Mazen Almehmadi, Amal F. Gharib, Ahmad El Askary, Tarek Alsayad, Alsufiany Muhsen, Hatem Allam Funding: The study was funded by the Deanship of Scientific Research, Taif University, Taif, KSA, for through the research group project number 1-441-95. Competing Interest: The authors have declared that no Open Access: This is an open-access article distributed under the terms of the Creative Commons Attibutiononcommercial 4.0 International

\section{Abstract}

BACKGROUND: Low Vitamin D levels associated with obesity have reached an epidemic level all over the world. It has been supposed that the low serum level of Vitamin D3 in obese subjects may be due to an increase in the uptake of Vitamin D3 by adipose tissue.

AIM: The current study aimed to investigate the effect of a specially designed exercise program for boosting lipolysis on the Vitamin D level in obese children.

METHODS: Thirty obese male children participated in the study. Their age was ranged from 9 to 11 years. The participants were assigned to two groups, Group I (GI) who received endurance exercise (ENE) only and Group II (GII) who received the specially designed exercise for increasing lipolysis (ENE preceded by resistance exercise). Free fatty acids (FFA), glycerol, and 25(OH)D were assessed before and immediately after exercise.

RESULTS: FFA and glycerol showed a significant increase in both groups following exercise, while $25(\mathrm{OH}) \mathrm{D}$ showed a significant increase only in GII. GIl showed significantly higher levels of FFA, glycerol, and 25(OH)D following exercise when it was compared to $\mathrm{Gl}$

CONCLUSION: The application of resistance training before ENE could improve the Vitamin D status through increasing the lipolytic activities more than the application of endurance exercise alone.

\section{Introduction}

Obesity is a medical impairment that has several influencing factors. Sedentary life, environmental factors, and bad eating habits all raise the incidence of obesity. Usually, obesity occurs because of increased calorie and fatty food intake. Furthermore, the lack of physical activities is considered the main factor to elevate the prevalence of obesity [1].

The incidence of obesity in the Kingdom of Saudi Arabia has reached a critical level. Al-Dossary et al. [2] studied the incidence of obesity and overweight in the Eastern province of Saudi Arabia. They reported that the prevalence of overweight and obesity was $(19.0 \%$ and $23.3 \%$, respectively). It was found that about $50 \%$ of teenagers have a body mass index (BMI) above the $85^{\text {th }}$ percentile. In addition, another study was done by El-Hazmi and Warsy [3] at Taif on 216 subjects concluded that about 95 of them were overweight.

Obesity associated with low Vitamin D levels has reached epidemic levels all over the world [4].
Adipose tissues are the main poles of Vitamin D3 in the body [5], [6], [7]. It has been reported that the high uptake of Vitamin D3 by adipose tissue may cause low Vitamin D3 serum levels in obese subjects. The adipose tissue may have an important role in the production's regulation of $25(\mathrm{OH}) \mathrm{D} 3$ in the liver [7]. The gradual release of Vitamin D3 from adipose tissue throughout fasting time has been reported by Wortsman et al. [5]. However, in normal conditions, the elevated accumulation of Vitamin $D$ in adipose tissue is not adequately secreted to general circulation to maintain serum 25(OH)D3 level. Wortsman et al. [5] reported that the correlation between obesity and Vitamin $D$ deficiency may be due to its deposition in the body fat compartments. In addition, Vimaleswaran et al. [8] stated that Vitamin D in the subcutaneous adipocyte has an important function that is to regulate the expression of adipocyte gene, which enhances the adipocyte production and impedes adipocyte apoptosis.

Aerobic and endurance exercises (ENEs) improve the lipolysis of white adipose tissue and mobilize free fatty acids (FFAs), so they can decrease 
adiposity [9], [10], [11]. In addition, it enhances the synthesis of certain proteins such as GLUT4 and PGC1 $\alpha$ [9], [11], [12]. Several studies [9], [10], [12], [13], [14] have mentioned that exercise training decreases the size of adipocyte and lipid contents and enhances the expression of GLUT4 and PGC1 $\alpha$ which have been noticed in the viscera and subcutaneous fatty tissues.

Adipose tissue is believed to be an important source of fatty acids and energy during aerobic training. Aerobic exercise improves blood flow in adipose tissue and increases fat mobilization through lipolysis as it stimulates insulin and adrenergic factors, and consequently, increases fatty acids supply to skeletal muscles [15], [16]. After frequent sessions of exercises, adipose tissue induces certain adaptations caused by enhancing the response to catecholamines, lipolysis, and increasing the serum level of lipids [17], [18], [19]. Such adaptation is associated with marked changes in gene expression [20], [21]. This effect lasts for more than $3 \mathrm{~h}$ after exercise, leading to considerable lipolysis and release of non-esterified fatty acids from adipose tissue into the circulation. It starts around $1 \mathrm{~h}$ post-exercise according to Narvaez et al. [21]. From the previously mentioned, the circulating Vitamin D required for lipogenesis can be uptaken through the adipose tissue causing Vitamin D deficiency, and at the same time, exercises can enhance lipolysis. Hence, the current study aimed to investigate the effect of a specially designed exercise program for boosting lipolysis on the Vitamin $D$ level in obese children. This may help in improving Vitamin D status without using Vitamin D supplements which could be a cause of weight gain that exacerbates the problem [22].

\section{Methods}

The current study was conducted between October 2020 and March 2021 at the physical therapy and laboratory departments, College of the Applied Medical Sciences, Taif University. The ethical approval was obtained from the research ethics committee, Taif University, Taif city, Saudi Arabia (approval number 42-0010) and the ethical committee at the research and studies department, Directorate of Health Affairs, Taif, Saudi Arabia (IBR Registration number with KACST, KSA HAP-02-T-067) (approval number, 428).

\section{Subjects}

Thirty obese male children participated in the study. The sample size was detected using the $\mathrm{G}^{*}$ Power (power, 0.95; $\alpha=0.05$; effect size $=0.7$, Pillai $V=0.33$ ). Their BMI percentile was equal to or greater than the $95^{\text {th }}$ percentile. Their ages were ranged from 9 to 11 years. They were selected from the elementary and primary schools at Taif. The subjects neither were involved in regular exercises nor took Vitamin D supplements or any medications that affect their Vitamin $D$ status during the past 3 months. The participants were excluded if they had previous injury or deformity of the lower extremities which required medical intervention or had other confounding conditions that affect their Vitamin D metabolism. In addition, they were excluded if they participated in weight reduction programs during the past 3 months.

The children's guardians had signed a written consent form before intervention. The simple randomization approach was used to assign the participants into two groups, Group I (GI) who received ENE only and Group II (GII) who received ENE preceded by resistance exercise. The study was double blinded, neither the participant nor the investigator was aware of the group to which the children belonged.

\section{Anthropometric measurements}

The subjects' body weight and height were detected using Seca 700 scale. The BMI was obtained by dividing the body weight in kilogram by the square of the height in meter. The BMI percentile was used to calculate the participant's degree of obesity according to the American Academy of Pediatrics recommendations. Whole-body DEXA measurements were done using the fan-beam mode to determine the total body fat mass. The children were examined while they were in the supine position with arms at their sides and wearing light clothes.

\section{Exercise intervention}

The exercise intervention was conducted at the physical therapy department from 9 to $11 \mathrm{am}$. Children in GI performed the endurance exercise (ENE) only while children in GIl were engaged in the resistance training followed by 20 min of rest then the endurance exercise (RREN) which significantly increases the lipolytic activities than ENE alone [23]. Light intensity treadmill training was used as endurance training. The Martti Karvonen formula was used to calculate the exercise intensity (exercise target heart rate $=$ heart rate reserve $(\mathrm{HRR}) \times 50 \%$ + rest-heart rate $(\mathrm{RHR})$. The formula "HRR= max-HR-RHR" was used to calculate the heart rate reserve while the formula "Max-HR = 220-age" was used to calculate the Max-HR. The speed of treadmill training was initially $2 \mathrm{~km} / \mathrm{h}$ and then was increased gradually by $0.5 \mathrm{~km} / \mathrm{h}$ every $1 \mathrm{~min}$ until reaching the exercise target heart rate which was maintained for $1 \mathrm{~h}$.

The resistance exercise intervention was adopted from Goto et al. [23]. The subjects in Gll came to the physical therapy department 2 days before the intervention from 9 to $11 \mathrm{am}$. The weight stack machine was utilized to determine the participant's one-repetition maximum (1RM) for pull-down, shoulder 
press, butterfly, arm curl, and squat exercises. A warm up of stretching exercises to the involved muscles and a set of 10 repetitions of the selected exercises using one plate which weighed 5 pounds was performed before determining the $1 \mathrm{RM}$. After a rest for $1 \mathrm{~min}$, the load gradually increased until the child was unable to perform the exercise. About $75 \%$ of the $1 \mathrm{RM}$ was used during the exercises' sets. The resistance training consisted of three sets of 10 repetitions for each exercise, with $1 \mathrm{~min}$ rest after each set.

\section{Blood analysis}

The instructions were given to the participants to fast $10-12 \mathrm{~h}$ before the intervention. All participants came to the physical therapy lab at the same time of the day from 9 to 11 am. Five milliliters of blood were withdrawn just before and immediately after the exercise. Lipolysis was assessed using the serum level of the glycerol and the FFAs while Vitamin D was assessed using the $25(\mathrm{OH})$ vitamin $\mathrm{D}$ serum level. The examiner collected the blood in a tube without adding anticoagulants. The blood was centrifuged at 2500 $\times \mathrm{g}$ for $20 \mathrm{~min}$ after clotting at room temperature for $30 \mathrm{~min}$. The glycerol serum level was assessed using Cell Biolabs' free glycerol assay kit (Cat. No. STA-398) just before and immediately after the exercise. The kit measures free, endogenous glycerol by a coupled enzymatic reaction system. The glycerol produces hydrogen peroxide when it is phosphorylated and oxidized. The hydrogen peroxide reacts with the kit's colorimetric probe (absorbance maxima of $570 \mathrm{~nm}$ ). For the assessment of human FFA, we used Abcam FFA colorimetric assay kit (Cat. No. ab65341). 25(OH) vitamin $D$ serum level was analyzed using an ELISA assay kit (Abcam Human Vitamin D ELISA Kit, USA) (Cat No. ab213966).

\section{Study design and statistical analysis}

The current study is a clinical controlled trial. Statistical analysis was performed using SPSS version 26 for Windows. Repeated measure MANOVA within and between-subjects effect and Bonferroni pairwise comparison were used to determine the differences between the study groups and the influence of intervention within each group. The differences were considered significant when $p<0.05$ was considered.

\section{Results}

\section{Baseline comparisons}

The results of the current study revealed that there was no significant difference between the two groups before the intervention neither in the demographic data nor in the measured study variables (Table 1).

Table 1: Bonferroni pairwise comparisons for baseline characteristics of the study groups

\begin{tabular}{llll}
\hline Variables & $\mathrm{Gl} \mathrm{M} \pm \mathrm{SD}$ & $\mathrm{GII} \mathrm{M} \pm \mathrm{SD}$ & $\mathrm{p}$ \\
\hline Age & $10.29 \pm 1.14$ & $10.73 \pm 0.98$ & 0.263 \\
Height & $1.48 \pm 0.13$ & $1.49 \pm 0.14$ & 0.840 \\
Weight & $48.62 \pm 7.59$ & $48.31 \pm 7.91$ & 0.913 \\
BMI & $22.09 \pm 2.2$ & $21.64 \pm 2.13$ & 0.577 \\
BMI percentile & $96.60 \pm 1.06$ & $96.07 \pm 0.96$ & 0.159 \\
Total body fat mass $(\mathrm{kg})$ & $21 \pm 3.27$ & $19.75 \pm 3.6$ & 0.330 \\
25(OH) VD ng/ml & $17.23 \pm 5.33$ & $17.54 \pm 4.63$ & 0.410 \\
FFA mmol/L & $0.32 \pm 0.12$ & $0.29 \pm 0.08$ & 0.866 \\
Glycerol mmol/L & $0.56 \pm 0.12$ & $0.57 \pm 0.10$ & 0.859 \\
\hline M: Mean, SD: Standard deviation, BMl: Body mass index, FFA: Free fatty acid, Gl: Group I, GII: Group II.
\end{tabular}

\section{Within subjects comparisons}

The sphericity of data was not met, and the value of epsilon was $<0.75$ so the Greenhouse-Geisser adjustment was used to determine the within-subjects effect. Bonferroni pairwise comparisons revealed that serum levels of glycerol and FFA showed a significant increase immediately after exercise in both groups. Regarding the $25(\mathrm{OH}) \mathrm{D}$, there was a significant increase only in GIl post-intervention (Table 2).

\section{Between-subjects comparisons}

The study's data were homogenous. The data homogeneity was indicated by Levene's test of equality of error variances, which showed non-significant values. Between-subjects' effects showed a highly significant difference between both groups. Bonferroni pairwise comparisons showed a highly significant increase in the serum levels of the $25(\mathrm{OH}) \mathrm{D}, \mathrm{FFA}$, and glycerol following exercise in GII when it was compared with $\mathrm{GI}$ (Table 3).

\section{Correlation between 25(OH)D, FFA, and} glycerol post-exercise intervention

Pearson's correlation showed that there was a significant positive correlation between 25(OH)D, FFA, and glycerol following exercise intervention (Table 4).

\section{Discussion}

The current study was conducted to investigate the effect of a specially designed exercise program for boosting lipolysis on the Vitamin $D$ level in obese children. The findings of this study revealed that there was a significant increase in the serum level of FFA and glycerol following both ENE and RREN, while the 25(OH)D significantly increased only after RREN. Furthermore, the serum levels of FFA, glycerol, and 
Table 2: Greenhouse-Geisser test and Bonferroni pairwise within-subjects comparisons

\begin{tabular}{|c|c|c|c|c|c|c|c|c|}
\hline \multicolumn{9}{|c|}{ Greenhouse-Geisser } \\
\hline \multicolumn{3}{|c|}{ Source } & \multicolumn{3}{|c|}{$\mathrm{F}$} & \multicolumn{3}{|c|}{$\mathrm{p}$} \\
\hline \multirow{2}{*}{\multicolumn{3}{|c|}{$\begin{array}{l}\text { Variables*pre-post } \\
\text { Variables*pre-post*groups }\end{array}$}} & \multicolumn{3}{|l|}{20.761} & \multicolumn{3}{|c|}{0.000} \\
\hline & & & 4.201 & & & & & \\
\hline \multicolumn{9}{|c|}{ Bonferroni pairwise comparisons } \\
\hline \multirow[t]{2}{*}{ Variables } & \multicolumn{4}{|l|}{ GI } & \multicolumn{4}{|l|}{ GII } \\
\hline & $\begin{array}{l}\text { Pre-intervention } \\
\mathrm{M} \pm \mathrm{SD}\end{array}$ & $\begin{array}{l}\text { Post-intervention } \\
\mathrm{M} \pm \mathrm{SD}\end{array}$ & MD & $\mathrm{p}$ & $\begin{array}{l}\text { Pre-intervention } \\
M \pm S D\end{array}$ & $\begin{array}{l}\text { Post-intervention } \\
M \pm S D\end{array}$ & MD & $p$ \\
\hline $25(\mathrm{OH}) \mathrm{D} \mathrm{ng} / \mathrm{ml}$ & $17.23 \pm 5.33$ & $20.85 \pm 4.34$ & -3.62 & 0.051 & $17.54 \pm 4.63$ & $27.20 \pm 4.18$ & -9.67 & 0.000 \\
\hline FFA mmol/L & $0.32 \pm 0.12$ & $0.60 \pm 0.12$ & -0.28 & 0.000 & $0.29 \pm 0.08$ & $1.11 \pm 0.13$ & -0.821 & 0.000 \\
\hline Glycerol mmol/L & $0.56 \pm 0.12$ & $1.25 \pm 0.30$ & -0.69 & 0.000 & $0.57 \pm 0.10$ & $2.57 \pm 0.35$ & -1.2 & 0.000 \\
\hline
\end{tabular}

25(OH)D were significantly higher after RREN when it was compared with ENE immediately following exercise.

Petridou et al. [24] agreed with the current findings when they mentioned that the lipolytic activities during exercise are increased by ENEs, but these activities could be heightened if the resistance exercise and the endurance regimen are combined. Kraemer et al. [25] reported that high-intensity exercise is considered a powerful stimulus for intensifying endocrine activities. Catecholamine and growth hormone are considered the most important enhanced hormones which have a powerful lipolytic effect [26], [27] and are responsible for lipolysis and the increase in serum glycerol and FFA concentrations during the subsequent aerobic exercise [28]. From the same point of view, Thompson et al. [28] supported these results when they reported that a single bout of exercise increases the adipose tissue blood flow and enhances fat mobilization, resulting in a conveyance of FFA to the skeletal muscles at a rate compatible with metabolic necessities. They concluded that physical activity may lead to useful dynamic alterations in the adipose tissue in response to each exercise bout.

Table 3: Between-subjects effect and Bonferroni pairwise comparisons of the study variables

\begin{tabular}{|c|c|c|c|c|c|}
\hline \multicolumn{6}{|c|}{ Between-subjects effect } \\
\hline Source & \multicolumn{2}{|l|}{$\mathrm{F}$} & \multicolumn{3}{|c|}{$\mathrm{p}$} \\
\hline Groups & \multicolumn{2}{|c|}{13.501} & \multicolumn{3}{|c|}{0.001} \\
\hline \multicolumn{6}{|c|}{ Bonferroni pairwise comparisons } \\
\hline Variables & $\mathrm{Gl}(\mathrm{M} \pm \mathrm{SD})$ & $\mathrm{GII}(\mathrm{M} \pm \mathrm{SD})$ & MD & & $\mathrm{p}$ \\
\hline $25(\mathrm{OH}) \mathrm{D} \mathrm{ng} / \mathrm{ml}$ & $\begin{array}{l}20.85 \pm \\
4.34\end{array}$ & $27.20 \pm 4.18$ & -6.35 & & 0.000 \\
\hline FFA mmol/L & $0.60 \pm 0.12$ & $1.11 \pm 0.13$ & -0.51 & & 0.000 \\
\hline Glycerol mmol/L & $1.25 \pm 0.30$ & $2.57 \pm 0.35$ & -1.31 & & 0.000 \\
\hline
\end{tabular}

The results of the current study showed that the combination of resistance training and endurance training with 20 min of rest in between led to higher serum levels of FFA and glycerol when it was compared to endurance training alone. This came in agreement with Goto et al. [23] who conducted a study to investigate the influences of resistance exercise followed by endurance

Table 4: Correlation between 25(OH) D, FFA, and glycerol post-exercise intervention

\begin{tabular}{llll}
\hline & FFA & Glycerol & FFA \\
& post-25(OH) & post-25(OH) & post-glycerol \\
& D post & D post & post \\
\hline Pearson's correlation & $0.563^{\star *}$ & $0.612^{\star *}$ & $0.838^{\star *}$ \\
Sig. (two tailed) & 0.001 & 0.000 & 0.000 \\
\hline${ }^{* *}$ Correlation is significant at the 0.01 level (two tailed). Sig: Significant, FFA: Free fatty acid.
\end{tabular}

training on lipid metabolism at several recovery stages. They concluded that prior resistance training with a short recovery period (20 $\mathrm{min}$ ) had the best results regarding the increase in the lipolytic activities. Enevoldsen et al. [29] came inconsistent with these findings when they stated that the exercise training either in the fasted or in the fed state advances lipolysis approximately 2-3 times.

In addition, 25(OH)D showed a significant increase immediately after training with RREN when it was compared to pre-training or after training with ENE. This may be attributed to the increase in the adipose tissue lipolysis as when the stored triacylglycerol is hydrolyzed, Vitamin $D$ metabolites may also be released from the adiposities as reported by Hengist et al. [30].

Moreover, Sun et al. [31] confirmed the current study findings when they examined the effect of acute ENE on the $25(\mathrm{OH}) \mathrm{D}$ serum levels in young adults. They stated that the application of $30 \mathrm{~min}$ of cycling exercise at $70 \%$ maximal oxygen uptake significantly increased the $25(\mathrm{OH}) \mathrm{D}$ concentration immediately after exercise. They attributed these changes to the metabolic influences of exercise on body fat. From the same point of view, Żychowska et al. [32] coincided with the study results when they investigated the effect of fasting and exercises on Vitamin $\mathrm{D}$ metabolism. They mentioned that there was an increase in the serum 25(OH)D3 levels following exercises which may be related to the increased lipolytic activities. In addition, the results of Mieszkowsk et al. [33] supported the current study's results as they concluded that ultramarathon exercise significantly raises the serum levels of Vitamin D metabolites that may be due to mobilization of Vitamin $D$ from adipose tissue.

Furthermore, Aly et al. [34] reported that there was a negative correlation between Vitamin $D$ serum levels and triglycerides and low-density lipoprotein following a swimming exercise in induced type two diabetes in rats. They also found that the Vitamin $D$ receptors and Vitamin D levels were significantly increased post-intervention. On the other hand, Maïmoun et al. [35] detected 25(OH)D reduction following one session of exhausting exercises but they cannot determine the cause for these findings. They estimated that the elevation in parathormone levels or degradation of $25(\mathrm{OH}) \mathrm{D}$ may be the cause for these results. 


\section{Conclusion}

It could be concluded that the application of resistance training before ENE could improve the Vitamin D status through increasing the lipolytic activities more than the application of ENE alone.

\section{Limitations of the study}

The current study was limited by studying only the acute effect of the exercise as the study variables were measured once after exercise. Furthermore, the body type was not taken into consideration as one of the demographic data. This study depended only on the serum level of $25(\mathrm{OH}) \mathrm{D}$ to evaluate the Vitamin D status.

\section{Authors' Contributions}

H. H. Allam: Designed the study, wrote the discussion section, and edited the manuscript, L. K. Elsayyad: Designed the study, collected, and analyzed the data, and edited the manuscript, S. Alaa: Prepared the original draft, supervised the practical part, and edited the manuscript, A. Mazen: Planned, and conduct the investigations, wrote the review, and supervised the practical part, T. Alsayad: Conducted the initial examination, followed the participants' medical conditions, wrote the methodology, and reviewing the manuscript, E. Ahmad: Planned, and conduct the investigations, obtaining the ethical approval, withdrawing the blood samples, and editing the manuscript, and Amal F. Gharib: Conducted the initial examination, followed the participants' medical conditions, withdrew the blood samples, writing the discussion section, and revised the final version of the manuscript.

\section{References}

1. Ebbeling CB, Pawlak DB, Ludwig DS. Childhood obesity: Publichealthcrisis, commonsensecure. Lancet. 2002;360(9331):473-82. https://doi.org/10.1016/S0140-6736(02)09678-2

PMid:12241736

2. Al-Dossary SS, Sarkis PE, Hassan A, El Regal ME, Fouda AE. Obesity in Saudi children: A dangerous reality. East Mediterr Health J. 2010;16(9):1003-8.

PMid:21218729

3. El-Hazmi MA, Warsy AS. Prevalence of obesity in the Saud population. Ann Saudi Med. 1997;17(3):302-6. https://doi. org/10.5144/0256-4947.1997.302

PMid:17369727

4. Lawson DE, Douglas J, Lean M, Sedrani S. Estimation of
Vitamin D3 and 25-hydroxyvitamin D3 in muscle and adipose tissue of rats and man. Clin Chim Acta. 1986;157(2):175-81. https://doi.org/10.1016/0009-8981(86)90223-8

PMid:3013467

5. Wortsman J, Matsuoka LY, Chen TC, Lu Z, Holick MF Decreased bioavailability of Vitamin D in obesity. Am J Clin Nutr. 2000;72(3):690-3. https://doi.org/10.1093/ajcn/72.3.690 PMid:10966885

6. Sun X, Morris KL, Zemel MB. Role of calcitriol and cortiso on human adipocyte proliferation and oxidative and inflammatory stress: A microarray study. Lifestyle Genomics. 2008;1(1-2):30-48.

7. Landrier JF, Karkeni E, Marcotorchino J, Bonnet L, Tourniaire F. Vitamin D modulates adipose tissue biology: Possible consequences for obesity? Proc Nutr Soc. 2016;75(1):38-46. https://doi.org/10.1017/S0029665115004164 PMid:26564334

8. Vimaleswaran KS, Berry DJ, Lu C, Tikkanen E, Pilz S, Hiraki LT, et al. Causal relationship between obesity and Vitamin $\mathrm{D}$ status: Bi-directional Mendelian randomization analysis of multiple cohorts. PLoS Med. 2013;10(2):e1001383. https://doi. org/10.1371/journal.pmed.1001383

PMid:23393431

9. Arunabh S, Pollack S, Yeh J, Aloia JF. Body fat content and 25-hydroxyvitamin $\mathrm{D}$ levels in healthy women. J Clin Endocrinol Metab. 2003;88(1):157-61. https://doi.org/10.1210/ jc.2002-020978

PMid: 12519845

10. Hirshman MF, Wardzala LJ, Goodyear LJ, Fuller SP, Horton ED Horton ES. Exercise training increases the number of glucose transporters in rat adipose cells. Am J Physiol Endocrinol Metab. 1989;257(4):E520-30. https://doi.org/10.1152/ ajpendo.1989.257.4.E520

PMid:2801935

11. Sutherland LN, Bomhof MR, Capozzi LC, Basaraba SA, Wright DC. Exercise and adrenaline increase PGC-1 $\alpha$ mRNA expression in rat adipose tissue. J Physiol. 2009;587(7):1607-17. https:// doi.org/10.1113/jphysiol.2008.165464 PMid:19221126

12. Stallknecht B, Vinten J, Ploug T, Galbo H. Increased activities of mitochondrial enzymes in white adipose tissue in trained rats. Am J Physiol Endocrinol Metab. 1991;261(3):E410-4. https:// doi.org/10.1152/ajpendo.1991.261.3.E410 PMid: 1653528

13. Frayn KN. Fat as a fuel: Emerging understanding of the adipose tissue-skeletal muscle axis. Acta Physiol. 2010;199(4):509-18. https://doi.org/10.1111/j.1748-1716.2010.02128.x PMid:20353493

14. Stallknecht B, Dela F, Helge JW. Are blood flow and lipolysis in subcutaneous adipose tissue influenced by contractions in adjacent muscles in humans? Am J Physiol Endocrinol Metab. 2007;292(2):E394-9. https://doi.org/10.1152/ ajpendo.00215.2006 PMid:16985258

15. Crampes F, Beauville M, Riviere D, Garrigues M. Effect of physical training in humans on the response of isolated fat cells to epinephrine. J Appl Physiol. 1986;61(1):25-9. https://doi. org/10.1152/jappl.1986.61.1.25 PMid:3733612

16. Crampes F, Beauville M, Riviere D, Garrigues M, Lafontan M. Lack of desensitization of catecholamine-induced lipolysis in fat cells from trained and sedentary women after physical exercise. J Clin Endocrinol Metab. 1988;67(5):1011-7. https:// doi.org/10.1210/jcem-67-5-1011

PMid:3182955 
17. Fabre O, Ingerslev LR, Garde C, Donkin I, Simar D, Barres R. Exercise training alters the genomic response to acute exercise in human adipose tissue. Epigenomics. 2018;10(8):1033-50. https://doi.org/10.2217/epi-2018-0039 PMid:29671347

18. Rönn T, Volkov P, Tornberg Å, Elgzyri T, Hansson $\mathrm{O}$, Eriksson $\mathrm{KF}$, et al. Extensive changes in the transcriptional profile of human adipose tissue including genes involved in oxidative phosphorylation after a 6-month exercise intervention. Acta Physiol. 2014;211(1):188-200. https://doi.org/10.1111/ apha. 12247

PMid:24495239

19. Ruschke K, Fishbein L, Dietrich A, Klöting N, Tönjes A Oberbach A, et al. Gene expression of PPAR $\gamma$ and PGC-1 $\alpha$ in human omental and subcutaneous adipose tissues is related to insulin resistance markers and mediates beneficial effects of physical training. Eur J Endocrinol. 2010;162(3):515-23. https:// doi.org/10.1530/EJE-09-0767

PMid:19966034

20. AL Mulla N, Simonsen L, Bülow J. Post-exercise adipose tissue and skeletal muscle lipid metabolism in humans: The effects of exercise intensity. J Physiol. 2000;524(3):919-28. https://doi. org/10.1111/j.1469-7793.2000.00919.x PMid:10790168

21. Narvaez CJ, Matthews D, Broun E, Chan M, Welsh J. Lean phenotype and resistance to diet-induced obesity in Vitamin D receptor knockout mice correlates with induction of uncoupling protein-1 in white adipose tissue. Endocrinology. 2009;150(2):651-61. https://doi.org/10.1210/en.2008-1118 PMid: 18845643

22. Weber K, Erben RG. Differences in triglyceride and cholesterol metabolism and resistance to obesity in male and female Vitamin D receptor knockout mice. J Anim Physiol Anim Nutr (Berl). 2013;97(4):675-83. PMid:22548652

23. Goto K, Ishii N, Sugihara S, Yoshioka T, Takamatsu K. Effects of resistance exercise on lipolysis during subsequent submaximal exercise. Med Sci Sports Exerc. 2007;39(2):308-15. https://doi. org/10.1249/01.mss.0000246992.33482.cb PMid:17277595

24. Petridou A, Chatzinikolaou A, Avloniti A, Jamurtas A, Loules G, Papassotiriou I, et al. Increased triacylglycerol lipase activity in adipose tissue of lean and obese men during endurance exercise. J Clin Endocrinol Metab. 2017;102(11):3945-52. https://doi.org/10.1210/jc.2017-00168 PMid:28605462

25. Kraemer WJ, Marchitelli L, Gordon SE, Harman E, Dziados JE, Mello $\mathrm{R}$, et al. Hormonal and growth factor responses to heavy resistance exercise protocols. J Appl Physiol (1985). 1990;69(4):1442-50. https://doi.org/10.1152/jappl.1990.69.4.1442 PMid:2262468
26. Quisth V, Enoksson S, Blaak E, Hagström-Toft E, Arner P, Bolinder J. Major differences in noradrenaline action on lipolysis and blood flow rates in skeletal muscle and adipose tissue in vivo. Diabetologia. 2005;48(5):946-53. https://doi. org/10.1007/s00125-005-1708-4

PMid: 15778861

27. Stich V, De Glisezinski I, Berlan M, Bulow J, Galitzky J, Harant I, et al. Adipose tissue lipolysis is increased during a repeated bout of aerobic exercise. J Appl Physiol. 2000;88(4):1277-83. https://doi.org/10.1152/jappl.2000.88.4.1277

PMid:10749819

28. Thompson D, Karpe F, Lafontan M, Frayn K. Physical activity and exercise in the regulation of human adipose tissue physiology. Physiol Rev. 2012;92(1):157-91. https://doi.org/10.1152/ physrev.00012.2011

PMid:22298655

29. Enevoldsen LH, Simonsen L, Macdonald IA, Bülow J. The combined effects of exercise and food intake on adipose tissue and splanchnic metabolism. J Physiol. 2004;561(3):871-82. https://doi.org/10.1113/jphysiol.2004.076588

PMid:15498802

30. Hengist A, Perkin O, Gonzalez JT, Betts JA, Hewison M, Manolopoulos KN, et al. Mobilising Vitamin D from adipose tissue: The potential impact of exercise. Nutr Bull. 2019;44(1):25-35.

31. Sun X, Cao ZB, Taniguchi H, Tanisawa K, Higuchi M. Effect of an acute bout of endurance exercise on serum $25(\mathrm{OH})$ $\mathrm{D}$ concentrations in young adults. J Clin Endocrinol Metab. 2017;102(11):3937-44. https://doi.org/10.1210/jc.2017-00146 PMid:28973380

32. Żychowska M, Rola R, Borkowska A, Tomczyk M, Kortas J, Anczykowska $\mathrm{K}$, et al. Fasting and exercise induce changes in serum Vitamin $\mathrm{D}$ metabolites in healthy men. Nutrients. 2021;13(6):1963. https://doi.org/10.3390/nu13061963 PMid:34201027

33. Mieszkowski J, Stankiewicz B, Kochanowicz A, Niespodziński B, Kowalik T, Żmijewski M, et al. Ultra-marathon-induced increase in serum levels of vitamin d metabolites: A double-blind randomized controlled trial. Nutrients. 2020;12(12):3629. https:// doi.org/10.3390/nu12123629 PMid:33255807

34. Aly YE, Abdou AS, Rashad MM, Nassef MM. Effect of exercise on serum Vitamin $D$ and tissue Vitamin $D$ receptors in experimentally induced Type 2 diabetes mellitus. J Adv Res. 2016;7(5):671-9. https://doi.org/10.1016/j.jare.2016.07.001 PMid:27504197

35. Maïmoun L, Simar D, Malatesta D, Caillaud C, Peruchon E, Couret I, et al. Response of bone metabolism related hormones to a single session of strenuous exercise in active elderly subjects. Br J Sports Med. 2005;39(8):497-502. https://doi. org/10.1136/bjsm.2004.013151

PMid: 16046330 